\title{
EFFECTS OF TRAMADOL ON CHRYSOMYA ALBICEPS LARVAE AND ITS CONCENTRATION IN POSTMORTEM TISSUES AND LARVAE
}

\author{
Mohamed Elshehaby ${ }^{1}$, Mahran Tony ${ }^{1}$, Abd elbaset M.A. \\ Abd elreheem ${ }^{1}$, and Nora Z. Abdellah ${ }^{2}$ \\ Department of Zoology, Faculty of science, Al azhar University, Assiut, Egypt ${ }^{1}$ \\ Department of Forensic Medicine and Clinical Toxicology, Faculty of Medicine, Assiut \\ University, Egypt ${ }^{2}$
}

Nora Zeidan Abdellah

e-mail: nora.z.a@hotmail.com

\begin{abstract}
Background: The blowflies of Chrysomya albiceps are of medical and forensic importance because larvae of $C$. albiceps are the insects that are most commonly associated with corpses. Tramadol is a widely abused opioid with increased cases of overdose. Purpose: To evaluate the effect of tramadol on $C$. albiceps larvae and to determine tramadol level in the third larval stages of $C$. albiceps reared on tissue containing tramadol. Methods: $C$. albiceps was reared on rabbit tissues administered tramadol $(30.8 \mathrm{mg} / \mathrm{kg}$ dissolved in distilled water) by intraperitoneal injection twice daily for one week. The control group was reared on rabbits injected with distilled water. The third larval instar of $C$. albiceps was studied using scanning electron microscope. Biomorphic data (weight, length, and width) of larvae were documented and compared to those of the control group. Tramadol concentrations in postmortem livers, kidneys, and muscles from both treated and control groups were analyzed by high performance liquid chromatography (HPLC) immediately after scarification of rabbits. Results: Significant differences in the means of larval weights, lengths, and widths of tramadol and control group were observed. Ultrastructure changes were also detected in the tramadol reared group in the form of a dense compressed irregular shape larval body and deformed anterior and posterior ends. The concentration of tramadol in the third larval stage was $29.62 \mu \mathrm{g} / \mathrm{g}$, a level that was comparable to postmortem tissue concentration. Conclusions: The study established the effect of tramadol on the morphology of third larval instar of $C$. albiceps. These results indicate that tramadol retards larval development, thus interpretation and application of insects' data should be used with caution in forensic entomology when tramadol is suspected as a cause of death.
\end{abstract}

KEYWORDS: Calliphoridae, C. albiceps, Third instar larval stage, Tramadol

\section{INTRODUCTION}

Forensic entomology is the science that studies and utilizes data about insects and their developments, to assist in solving criminal cases (Kökdener, 2016). Insects are mainly used to estimate the postmortem interval (PMI) (Pujol-Luz et al. 2008). Chrysomya albiceps, is one of the most forensically important blowfly. Adults of C. albiceps feed on carcasses and garbage (Sukontason et al., 2000). Larvae of $C$. albiceps are also known as a cause of infesting living humans and animals causing myiasis (Sukontason et al., 2005). C. albiceps flies appear early on human corpses and have a rapid rate of reproduction (Vásquez and Liria, 2012). Furthermore, C. albiceps larvae are considered the most important consumer of decomposing tissues (Fouda et al., 2017). The presence of drugs or toxins in decomposing corpses affects the growth rate of insect development, which could be an important cause of inaccurate estimation of PMI (Verma and Paul, 2013). 
Entomotoxicology, which is one of the newest aspects of forensic entomology, involves toxicological and molecular examinations of insects to help in elucidating the cause of death. The analysis of larvae found in corpses can assist in the detection of drugs and toxins present in the corpses (Introna et al., 2001). Concentrations of drugs and toxins in larvae could be correlated to concentrations in tissues consumed by the larvae, giving a valuable clue about the cause of death (Campobasso et al., 2004). The effects of larvae on many chemicals are not well understood; therefore, their use for quantitative analysis of drugs or toxins is very limited (Ivey, 2011). Tramadol is an analgesic, which acts centrally via opioid receptors and non-opioid mechanism. It is used in the relief of moderate to severe pain and commonly abused (Rahimi et al., 2014). It was reported that tramadol dependence, intentional overdose or intoxication has been increased in recent years (Costa et al., 2013).

This study aims to explore the effects of tramadol on $C$. albiceps third instar larvae through Scanning Electron Microscopy (S.E.M.) examination and to estimate postmortem concentration of tramadol in tissue and c. albiceps larvae.

\section{Materials and Methods}

Six adult male rabbits (850- $900 \mathrm{gm}$ ) aged 4-6 months were used for rearing one generation of insects as the Diptera order of arthropods highly attracted to invade the rabbit carcasses (Padonou et al, 2017). The rabbits were housed in iron cages for two weeks acclimatization period in the insect's laboratory of Zoology Department, faculty of science at Al-Azhar University (Assiut) for acclimation at $30 \pm 4$ ${ }^{\circ} \mathrm{C}$, under a light-dark cycle (12:12 h) with ad-libitum food and water. After the acclimation period, rabbits were divided randomly into two groups.

Group one (control): Rabbits of this group were administrated distilled water through intraperitoneal injection (IP) twice daily for 1 week.

Group two (Tramadol): Rabbits of this group were administrated tramadol through IP in a dose of $30.8 \mathrm{mg} / \mathrm{kg}$ body weight twice daily for 1 week until the sacrificing of each animal. A toxic dose of $30.8 \mathrm{mg} / \mathrm{kg}$ rabbit was calculated according to Paget and Barnes (1964) as equivalent to 2 times the maximum recommended adult human dose. Blood samples were withdrawn from the retroorbital sinus of each rabbit (from both treated and control groups) at zero time, $12 \mathrm{~h}$ and $24 \mathrm{~h}$ after the initial dose administration before scarifying rabbits. After the end of the study period, rabbits were sacrificed by cervical dislocation. Samples of liver, kidney, and muscles were taken after death ( $1 \mathrm{~g}$ of each tissue).

- Thirty adult $C$. albiceps flies (20 females and 10 males) were collected and identified for taxonomic determinations by using current keys (Carvalho and MelloPatiu, 2008), and by medical Entomologists in Cairo University and insect collection of Ministry of Agriculture, Dokki, Giza, Egypt. After identification, flies were transferred in cages and maintained under controlled conditions of mean temperature of $30 \pm 4^{\circ} \mathrm{C}$, daily light /dark period of $12: 12 \mathrm{~h}$ and relative humidity of $60 \pm 10 \%$. The cages were protected with an external net curtain to avoid the entry of other insect species Whitworth (2006). After the death of the rabbits, the adult flies were reared on the cadavers of rabbits that were divided into control and tramadol groups. Hatching of eggs were checked every three hours. Larvae, pupae and adults were checked every twelve hours until the emergence of adults (Spiller (1996).

Biomorphic studies: The following morphometric characters are measured for the $C$. albiceps larvae at different time intervals (0h, 12h, 24h, 36h, 48h, 60h, 72h, 84h, 96h, 108h):

- Larval body weight: larvae were placed on filter paper in Petri dishes for 
measuring larval body weight (mg) by using digital electric balancer.

- Length: the maximum length (mm) from the anterior to the posterior end of the body of larvae measured using Verneer Caliper

- Width: the maximum distance (mm) between two points from right pleura to left pleura of the body of larvae using Verneer Caliper. Spiller (1996).

Sampling of larvae for quantitative analysis of tramadol:

Five days after hatching of eggs, 20 larvae of third instars were collected randomly from all carcasses of rabbits of both treated and control groups and then were rinsed in phosphate buffer, wrapped in a piece of aluminum foil and instantly frozen at $-80^{\circ} \mathrm{C}$ till toxicological analysis (Gagliano-Candela and Aventaggiato, 2001).

\section{Sample analysis and HPLC conditions}

The concentrations of tramadol in blood, liver, kidney, muscles, and larvae from both treated and control groups were analyzed by HPLC (Agilent 1260) with UV-Visible spectrophotometric detector at $218 \mathrm{~nm}$. The separation was carried out using Eclipse Plus C18 column (4.6 mm x $100 \mathrm{~mm}$ ), The mobile phase consisted of 0.1 trifloroacetic acid in water: acetonitrile: methanol $(70: 25: 5 \mathrm{v} / \mathrm{v})$ at a flow rate 1 $\mathrm{ml} / \mathrm{min}$. The injection volume was $20 \mu \mathrm{l}$ for each of the sample solutions. The column temperature was maintained at $40{ }^{\circ} \mathrm{C}$.

\section{Scanning Electron Microscopy} (SEM): The third instar larvae were collected, prepared and examined by (JEOL J SM-5400) scanning microscopy (Collwell and O'Connor, 2000).

The study was done after approval of ethics committee of Faculty of Medicine, Assiut University, according to the Guidelines of the National Institutes of Health for Animal Care (ILAR, 2011).

Statistical analysis: Data was analyzed using SPSS software version 22. Data was expressed as mean \pm Standard deviation
(SD), $\mathrm{p}$ value $<0.05$ was considered significant and Independent samples T-test used to compare means.

\section{RESULTS}

Tables (1,2 and 3) show means of larval weights, lengths, and widths at different time intervals $(0 \mathrm{~h}, 12 \mathrm{~h}, 24 \mathrm{~h}, 36 \mathrm{~h}$, 48h, 60h, 72h, 84h, 96h, 108h). Significant differences in means of larval weights, lengths and widths were observed for all measurements at different intervals.

The means of weights of the larvae reared on tramadol treated rabbits and those of the control group are presented in table (1). Larvae from the tramadol group showed an increase from $0.20 \pm 0.01 \mathrm{mg}$ at zero hour to $61.6 \pm 0.9 \mathrm{mg}$ at 108 hours with the control recording weight increase from $0.3 \pm 0.18 \mathrm{mg}$ to $80.1 \pm 1.9 \mathrm{mg}$ at the same time.

The lengths means of the larvae reared on tramadol treated rabbits and the control groups are presented in table (2). The results show that the mean length of larvae of C. albiceps reared on tramadol treated rabbits was $1.2 \pm 0.33 \mathrm{~mm}$ at $0 . \mathrm{h}$ and reached $11 \pm 0.49 \mathrm{~mm}$ at $108 \mathrm{~h}$. This is significantly lower than lengths means of control larvae that had lengths means of $1.9 \pm 0.12 \mathrm{~mm}$ at $0 \mathrm{~h}$ and $13.2 \pm 0.29 \mathrm{~mm}$ at $108 \mathrm{~h}$.

The means of the larval widths of the tramadol and the control groups are presented in table (3). The results show that the mean width of larvae of C. albiceps reared on tramadol treated rabbits was 0.02 $\mathrm{mm}$ at $0 . \mathrm{h}$ and reached $2.8 \pm 0.07 \mathrm{~mm}$ at 108 $\mathrm{h}$. This is significantly lower than widths means of control larva that had width mean of $0.03 \mathrm{~mm}$ at $0 \mathrm{~h}$ and $3.5 \pm 0.2 \mathrm{~mm}$ at 108 $\mathrm{h}$.

Regarding tramadol concentrations in blood and tissue samples from the rabbits that were administered tramadol, the highest tramadol concentrations were detected in blood and liver of rabbit recording $39.59 \mu \mathrm{g} / \mathrm{ml}$ and $33.46 \mu \mathrm{g} / \mathrm{g}$, respectively followed by kidney (26.16 $\mu \mathrm{g} / \mathrm{g})$ and muscles $(20.23 \mu \mathrm{g} / \mathrm{g})$. 
The concentrations of tramadol are significantly decreased in blood with the passing of time after the initial tramadol dose $(63.86 \mu \mathrm{g} / \mathrm{ml}$ at zero $\mathrm{h}$ to $39.59 \mu \mathrm{g} / \mathrm{ml}$ after $24 \mathrm{~h}$ ). Concentration of tramadol in the feeding third instar of $C$. albiceps was $29.62 \mu \mathrm{g} / \mathrm{g}$. Table (4).

Ultrastructural examination of $\mathrm{C}$. albiceps third instar larvae of the control tramadol groups revealed normal larval bodies with normal appearance of the posterior end (Fig.1). The control larvae demonstrated normal appearance of the anterior end with normal hooks and normal anterior respiratory spiracles (Fig. 2). The Posterior end of the control larvae demonstrated normal processes and normal posterior respiratory spiracles (Fig.3).

Ultrastructural examination of $\mathrm{C}$. albiceps third instar larvae reared on tramadol treated rabbits, demonstrated dense compressed shape arched body and deformed anterior end with much smaller in size mouth hooks, deformed small-sized anterior respiratory spiracles. The posterior respiratory spiracles revealed hypogenesis compared to the control larvae (Figs 4\&5).

Table 1: Means of larval weights of $C$.albiceps that fed on tissues of rabbits administered tramadol hydrochloride in comparison to the control group at different intervals.

\begin{tabular}{|l|l|l|l|}
\hline \multirow{2}{*}{ Time } & \multicolumn{2}{l|}{ Weight in mg } & P value \\
\cline { 2 - 4 } & control & Tramadol & 0.012 \\
\hline $0 \mathrm{~h}$ & $0.3 \pm 0.18$ & $0.20 \pm 0.01$ & 0.021 \\
\hline $12 \mathrm{~h}$ & $0.9 \pm 0.16$ & $0.28 \pm 0.05$ & 0.000 \\
\hline $24 \mathrm{~h}$ & $4.36 \pm 0.86$ & $2 \pm 0.13$ & 0.000 \\
\hline $36 \mathrm{~h}$ & $5.3 \pm 0.37$ & $3.6 \pm 0.19$ & 0.000 \\
\hline $48 \mathrm{~h}$ & $6.3 \pm 0.07$ & $3.9 \pm 0.14$ & 0.000 \\
\hline $60 \mathrm{~h}$ & $12.6 \pm 0.47$ & $6.8 \pm 0.20$ & 0.000 \\
\hline $72 \mathrm{~h}$ & $23.5 \pm 0.53$ & $14.9 \pm 0.49$ & 0.000 \\
\hline $84 \mathrm{~h}$ & $38.8 \pm 0.77$ & $25.6 \pm 0.36$ & 0.000 \\
\hline $96 \mathrm{~h}$ & $60.25 \pm 1.05$ & $46.2 \pm 1.1$ & 0.000 \\
\hline $108 \mathrm{~h}$ & $80.1 \pm 1.9$ & $61.6 \pm 0.9$ & 0.000 \\
\hline
\end{tabular}

$\mathrm{P}$-value $<0.05$ considered significant 
Table (2): Means of larval lengths of $C$.albiceps that fed on tissues of rabbits administered tramadol hydrochloride in comparison to the control group at different intervals.

\begin{tabular}{|l|l|l|l|}
\hline \multirow{2}{*}{ Time } & \multicolumn{2}{|c|}{ length in mm } & \multirow{2}{*}{ P value } \\
\cline { 2 - 4 } & Control & Tramadol & \\
\hline $0 \mathrm{~h}$ & $1.9 \pm 0.12$ & $1.2 \pm 0.33$ & 0.000 \\
\hline $12 \mathrm{~h}$ & $2.4 \pm 0.09$ & $1.6 \pm 0.32$ & 0.000 \\
\hline $24 \mathrm{~h}$ & $4.5 \pm 0.08$ & $3 \pm 0.16$ & 0.000 \\
\hline $36 \mathrm{~h}$ & $5.2 \pm 0.14$ & $3.8 \pm 0.07$ & 0.000 \\
\hline $48 \mathrm{~h}$ & $6.6 \pm 0.13$ & $4.4 \pm 0.08$ & 0.000 \\
\hline $60 \mathrm{~h}$ & $7.6 \pm 0.15$ & $5.6 \pm 0.1$ & 0.000 \\
\hline $72 \mathrm{~h}$ & $10.5 \pm 0.29$ & $7.5 \pm 0.13$ & 0.000 \\
\hline $84 \mathrm{~h}$ & $11.3 \pm 0.41$ & $9.6 \pm 0.2$ & 0.000 \\
\hline $96 \mathrm{~h}$ & $12.5 \pm 0.24$ & $10.4 \pm 0.17$ & 0.000 \\
\hline $108 \mathrm{~h}$ & $13.2 \pm 0.29$ & $11 \pm 0.49$ & 0.000 \\
\hline
\end{tabular}

P-value $<0.05$ considered significant

Table (3): Means of larval widths of $C$.albiceps that fed on tissues of rabbits administered tramadol hydrochloride in comparison to the control group at different intervals.

\begin{tabular}{|l|l|l|l|}
\hline \multirow{2}{*}{ Time } & \multicolumn{2}{|c|}{ width in mm } & \multirow{2}{*}{ P value } \\
\cline { 2 - 3 } & \multicolumn{1}{|c|}{ Control } & Tramadol & \\
\hline $0 \mathrm{~h}$ & $0.03 \pm 0.00$ & $0.02 \pm 0.00$ & 0.001 \\
\hline $12 \mathrm{~h}$ & $0.31 \pm 0.1$ & $0.19 \pm 0.05$ & 0.005 \\
\hline $24 \mathrm{~h}$ & $1.2 \pm 0.12$ & $1 \pm 0.04$ & 0.000 \\
\hline $36 \mathrm{~h}$ & $1.3 \pm 0.07$ & $1.18 \pm 0.04$ & 0.000 \\
\hline $48 \mathrm{~h}$ & $1.7 \pm 0.06$ & $1.5 \pm 0.08$ & 0.000 \\
\hline $60 \mathrm{~h}$ & $2.2 \pm 0.09$ & $1.9 \pm 0.19$ & 0.001 \\
\hline $72 \mathrm{~h}$ & $2.7 \pm 0.1$ & $2.1 \pm 0.06$ & 0.000 \\
\hline $84 \mathrm{~h}$ & $3 \pm 0.3$ & $2.3 \pm 0.29$ & 0.000 \\
\hline $96 \mathrm{~h}$ & $3.2 \pm 0.06$ & $2.5 \pm 0.25$ & 0.000 \\
\hline $108 \mathrm{~h}$ & $3.5 \pm 0.2$ & $2.8 \pm 0.07$ & 0.000 \\
\hline
\end{tabular}

$\mathrm{P}$-value $<0.05$ considered significant 
Table 4: Concentrations of tramadol in blood and postmortem tissues of rabbits administered tramadol hydrochloride and in third instar larvae of $C$.albiceps.

\begin{tabular}{|c|c|c|c|c|c|c|}
\hline & Contr & & & Trama & & \\
\hline \multirow[t]{2}{*}{ Blood (ug/ml) } & Zero h & $12 \mathrm{~h}$ & $24 \mathrm{~h}$ & Zero h & $12 \mathrm{~h}$ & $24 \mathrm{~h}$ \\
\hline & 0 & 0 & 0 & 63.86 & 58.02 & 39.59 \\
\hline Liver (ug/g) & \multicolumn{3}{|c|}{0} & \multicolumn{3}{|l|}{33.46} \\
\hline Kidney (ug/g) & \multicolumn{3}{|c|}{0} & \multicolumn{3}{|l|}{26.16} \\
\hline Muscle (ug/g) & \multicolumn{3}{|c|}{0} & \multicolumn{3}{|l|}{20.23} \\
\hline Third Instar Larvae (ug/g) & \multicolumn{3}{|c|}{0} & \multicolumn{3}{|l|}{29.62} \\
\hline
\end{tabular}

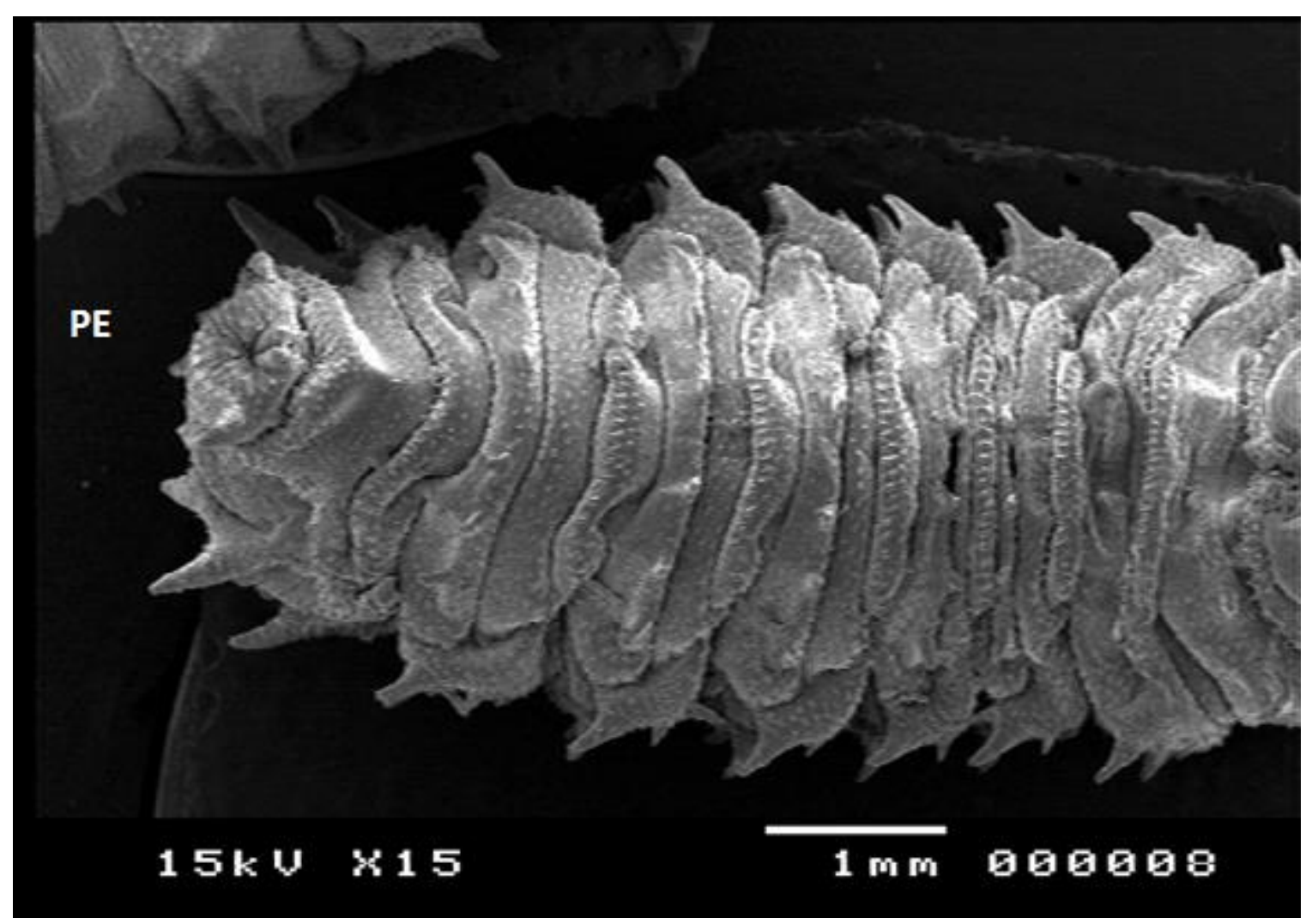

Figure (1): Scanning electron micrograph of the third instar larva of C. albiceps of the control group showing ventral aspect of the normal larval body and posterior end (PE). 


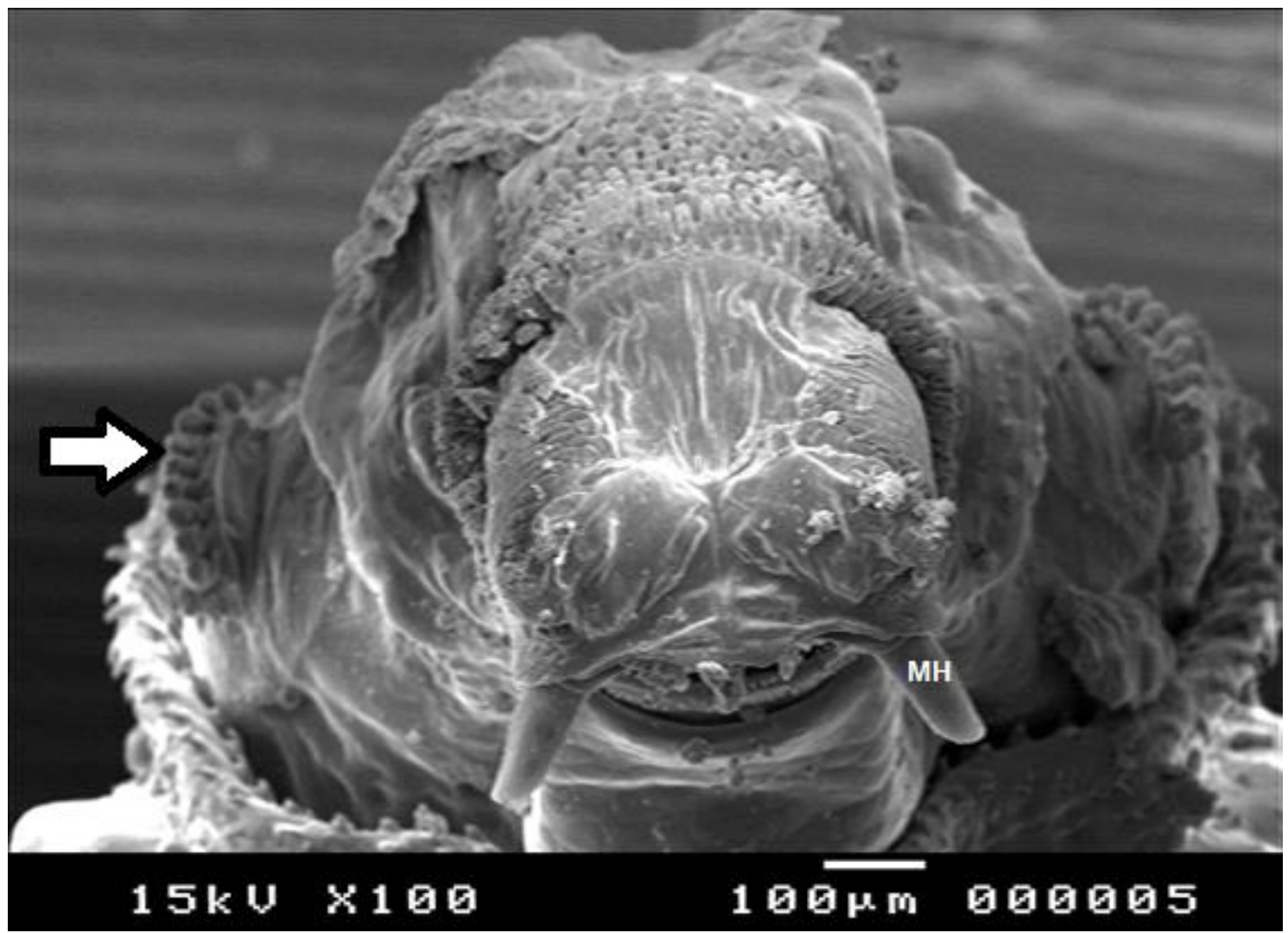

Figure (2): Scanning electron micrograph of third instar larvae of C. albiceps of the control group showing fronto-dorsal aspect of normal cephalic segment with normal mouth hooks (MH). and normal fan shaped anterior respiratory spiracles.

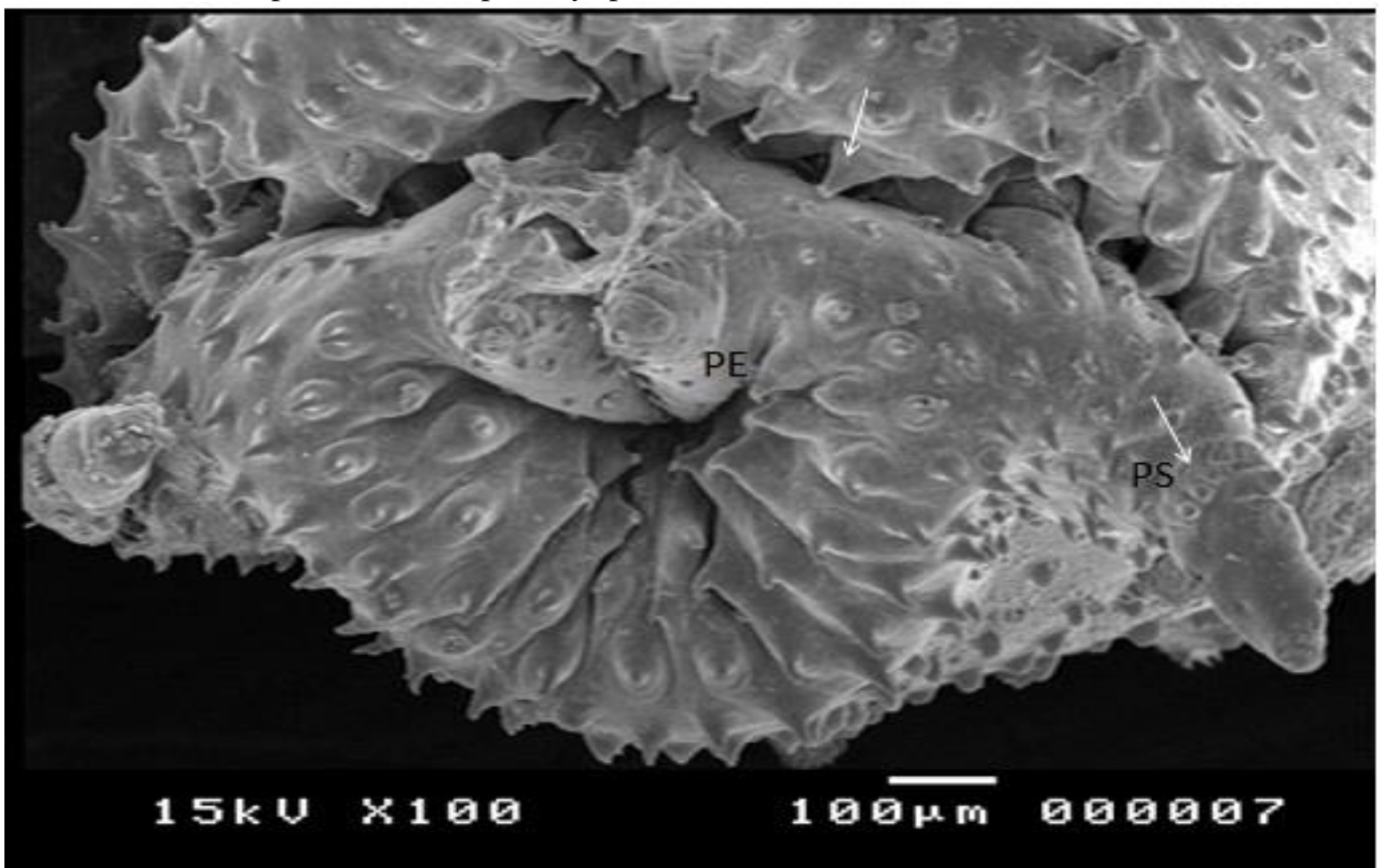

Figure (3): Scanning electron micrographs of control third instar larvae of C. albiceps showing posterior end with normal posterior respiratory spiracles (PS) and spines (arrow). 


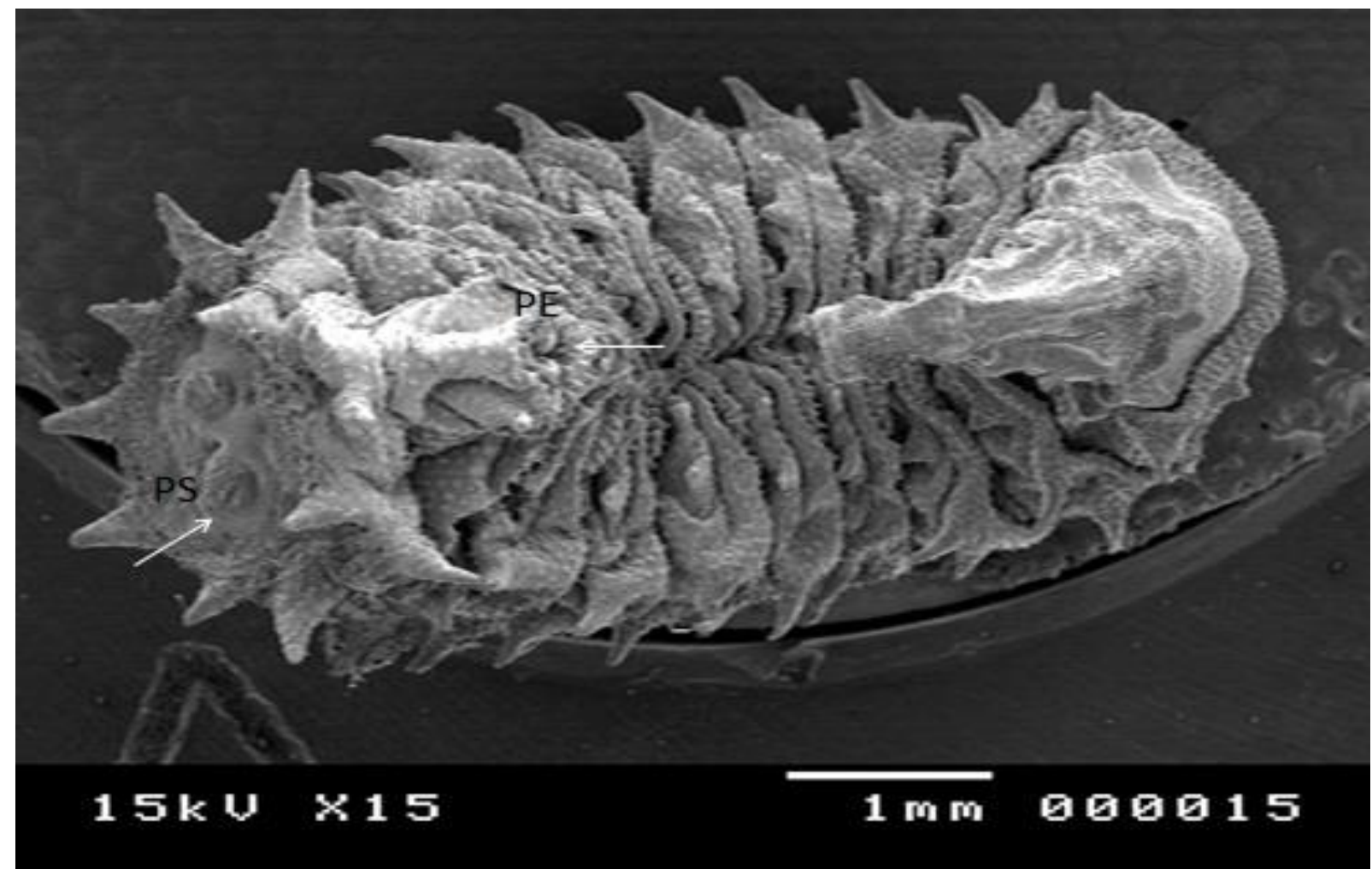

Figure (4): Scanning electron micrograph of third instar larva of C. albiceps of Tramadol group showing ventral aspect of shrinked compressed larval body with hypogenesis of posterior respiratory spiracles (PS) at the posterior end (PE).

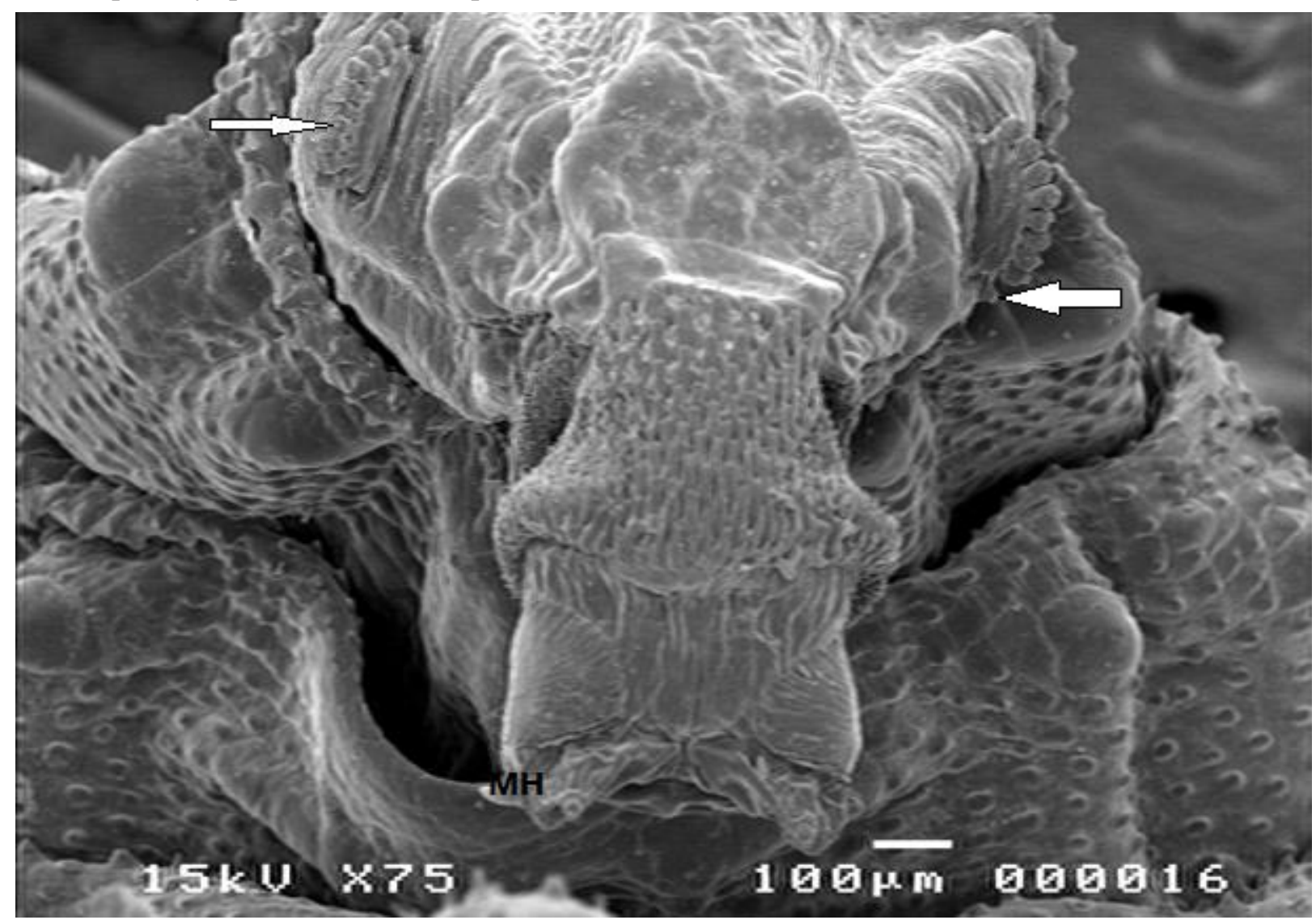

Figure (5): Scanning electron micrograph of third instar larva of C. albiceps of tramadol group showing fronto-dorsal aspect of cephalic segment showing small mouth hooks (MH) and deformed small anterior respiratory spiracles (arrows). 


\section{DISCUSSION}

Forensic entomology is the science of using and analyzing insect evidence to help in forensic investigations. It is mainly applied for the determination of PMI, either by estimating the age of the oldest insects found on the corpse or by analyzing the composition of insect species found. It was reported that the presence of drugs in decomposing tissues could alter the rate of development of insects, resulting in an inaccurate estimation of PMI. Insects could act as reliable alternative specimens for toxicological analysis when body fluids and tissues are absent or not valid for analysis (Chen et al., 2004 and Amendt et al., 2011).

Many studies have reported that the presence of drugs and toxins can alter growth rates of insects feeding on decaying corpses (Tabor et al., 2004). Salimi et al. (2018) demonstrated possible underestimation of PMI based on the faulty interpretation of the development of $C$. albiceps larvae reared on the tissues of rabbits carcasses containing morphine. By contrast, work by Kharbouche et al., (2008), showed an increased rate of development for larvae of Lucilia sericata and of Boettchersica peregrine reared on minced pig liver containing different codeine concentrations. Thus, the same species could react differently toward two molecules belonging to the same family

The present work revealed that larvae reared on decomposing tissue-containing tramadol had significantly retardation of development in comparison with the control group as the means of weights, lengths and widths of the tramadol group were significantly lower than those of the control larvae at different time intervals.

The current results are not consistent with the work of El-Samad et al., (2011) who demonstrated that Lucilia sericata larvae reared on rabbits administered tramadol had prolonged developmental period. Another study also reported that sarcophaga argyrostoma larvae reared on rat carcasses containing tramadol had significantly longer total body length as compared to the control larvae. However, pupation of the larvae was delayed for 2 days (AbouZied, 2016).

Inconsistent with our results, a recent study also revealed that weight, length of C. albiceps larvae and their developmental periods were affected by tramadol differently. Whereas the larvae from tramadol reared group gained body length and weight better than the control groups (Ekrakene and Odo, 2017). Thus, Tramadol and other opioids were reported to have two different effects on the calliphoridae larvae. Some studies reported that tramadol accelerates the development of the larvae while other studies revealed that it retards larval development.

In the present work, examination of $\mathrm{C}$. albiceps by SEM revealed that third instar larvae reared on tramadol administered rabbits, demonstrated dense compressed body with deformed appearance of the anterior end, which was much smaller in size, with small oral hooks and deformed small-sized spiracles. The posterior end was deformed with abnormal processes. The posterior respiratory spiracless also showed hypogenesis. Consistent with our results, the opiate drug codeine was reported to cause morphological changes in C. albiceps larvae. Those changes were in the form of deformed body segments, abnormalities in the shape of anterior and posterior spiracles. However, the same study reported that codeine accelerates the development rate during life cycle of $\mathrm{C}$. albiceps (Fathy et al., 2008).

Although, antemortem blood concentrations of drugs can be used to estimate the amount of administered drug, this is not always possible in postmortem cases. The postmortem blood concentrations do not accurately reflect the blood concentrations at the time of death mainly due to postmortem redistribution (Skopp et al., 1996). After death, drugs are redistributed to the surrounding tissues either by diffusion through blood vessels or by trans-parietal diffusion towards the 
surrounding organs (Pélissier-Alicot et al., 2003).

Insects may represent the main samples available for postmortem toxicological analysis. Few literature deals with the potential toxicological value of necrophagous insect larvae (Mergaoui et al., 2007). Regarding postmortem tramadol concentration in rabbit tissues, the present results showed that the highest concentration was in liver tissue (33.47 $\mu \mathrm{g} / \mathrm{g})$ followed by the kidney $(26.17 \mu \mathrm{g} / \mathrm{g})$ then muscles $(20.23 \mu \mathrm{g} / \mathrm{g})$. This is in agreement with the work of El-Samad et al. (2011), who detected tramadol by (HPLC) in various organs of experimentally injected rabbits, including the liver. Essentially, most drugs of abuse are detectable in muscle, so the present study supports this concept as tramadol was detected in muscles (Gock et al., 1999). Tramadol excretion is mainly through the renal route with a mean halflife of approximately 5 hours, Thus tramadol and its metabolite Odesmethyltramadol can be detected in renal tissue (Pothiawala and Ponampalam, 2011). In a case report of tramadol overdose death, tramadol was detected in concentrations of $20 \mathrm{mg} / \mathrm{L}, 68.9 \mathrm{mg} / \mathrm{kg}$ and $37.5 \mathrm{mg} / \mathrm{kg}$ in postmortem blood, liver and kidney samples respectively (Moore et al., 1999).

The present study revealed that the concentration of tramadol in third instar larvae was $29.62 \mu \mathrm{g} / \mathrm{g}$, which is comparable to postmortem rabbits' tissue concentrations. This is supported by the work of Introna et al. (1990) who reported that the concentrations of morphine in the larvae of $\mathrm{C}$. vicina reared on decomposing liver tissues of humans that were deceased and the cause of their death was morphine poisoning were strongly correlated to post mortem tissue concentrations. On the contrary Nolte et al. (1992) reported that concentrations of cocaine in larvae were significantly lower than those observed in tissues. It was reported that morphine and phenobarbital were detected in Calliphoridae larvae developed on cadavers of chronic heroin abusers 2 months after their death (Kintz et al, 1990).

It was postulated that the metabolism and elimination of various drugs by larvae vary significantly throughout larval developmental stages with a decrease in drug concentrations in post-feeding larvae suggesting that actively feeding and fully developed larvae only should be used as a sample for toxicological analysis (Hedouin et al., 2001).

\section{CONCLUSION}

The present work showed that tramadol caused the third instar larvae of C. albiceps to have abnormal fused small sized respiratory spiracles and deformed small posterior end with hypogenesis of the posterior respiratory spiracles. The results also indicate that tramadol is capable of causing a significant decrease in weight, length, and width of $C$. albiceps third instars larvae that could affect PMI estimation. Additional studies using different species of Calliphoridae and Sarcophagidae are needed as there may be different responses to the drug.

\section{REFERENCES}

AbouZied, E. (2016): Postmortem Attraction of Sarcosaprophagous Diptera to Tramadol-Treated Rats and Morphometric Aspects of the Developed Larvae. Neotrop Entomol, 45(3):326-332.

Amendt, J.; Richards,C.S.; Campobasso, C.P.; Zehner, R. and Hall MJ. (2011): Forensic Entomology: Applications and Limitations. Forensic Sci Med Pathol., 7:379-392.

Campobasso, C.; Gherardi, M.; Caligara, M.; Sironi, L. and Introna F. (2004): Drug Analysis in Blowfly Larvae and in Human Tissues: A Comparative Study. Int J Med Toxicol Legal Med., 118:210-214. 
Carvalho, C.JB. and Mello-Pati CA. (2008): Key to the Adults of the Most Common Forensic Species of Diptera in South America. Rev. Bras. Entomol., 52: 390-406

Chen, WY.; Hung, TH. and Shiao, SF. (2004): Molecular Identification of Forensically Important Blowfly Species (Diptera: Calliphoridae) in Taiwan. J Med Entomol., 41(1):47-57.

Collwell, D. and O Connor, M. (2000): Scanning Electron Microscopy of Sarcophagid (Diptera) Larvae Recovered from a Case of Human Cutaneous Myiasis. J.Med.Entomol., 37(6):854-859.

Costa, I.; Oliveira, A.; Guedes de Pinho P.; Teixeira, H.M.; Moreira, R.; Carvalho F. et al. (2013): Postmortem Redistribution of Tramadol and O-Desmethyltramadol. J Anal Toxicol., 37(9):670-675

Ekrakene, T. and Odo, P.E. (2017): Comparative Developmental Effects Of Tramadol Hydrochloride and Cypermethrin on Chrysomya Albiceps (Weid.) (Diptera: Calliphoridae) Reared on Rabbit Carrions. Sci World J., 12 (1): 28-32.

El-Samad, L.; El-Moaty, Z. and Makemer, H. (2011): Effects of Tramadol on the Development of Lucilia sericata (Diptera: Calliphoridae) and Detection of the Drug Concentration in Postmortem Rabbit Tissues and Larvae. J. Entomol., 8: 353-364.

Fathy, H.M.; Attia, R.A.H.;Yones, D.A.; Eldeek, H.E.; Tolba, M.E. and Shaheen, M.S. (2008): "Effect of codeine phosphate on developmental stages of forensically important calliphoride fly: chrysomya albiceps". Mansoura J. Forensic Med. Clin. Toxicol., 16(1): 41-59.

Fouda, M.A.; Al- Dali, A.G.; Hammad, K.M.; Abdrabou, M.M. and Kabadaia, M.M. (2017): Entomotoxicological Study on the Forensic Blowflies Chrysomya Albiceps Associated with Dog
Carcass. Egypt. Acad. J. Biolog. Sci., 10(6): 107-121.

Gagliano-Candela,

R1. and Aventaggiato, L. (2001): The Detection of Toxic Substances in Entomological Specimens. Int J Legal Med., 114(4-5):197-203.

Gock, S.B.; Wong, S.H.; Nuwayhid, N.; Venuti, S.E.; Kelley, P.D.; Teggatz, J.R. et al. (1999): Acute Zolpidem Overdose- Report of Two Cases. J. Anal.Toxicol., 23: 559-562.

Hedouin, V.; Bourel, B.; Becart, A.; Tournel, G.; Deveaux, A.; Doff, M.L. et al. (2001): Determination of Drug Levels in Larvae of Protophormia Terraenovae and Calliphora Vicina (Diptera: Calliphoridae) Reared on Rabbit Carcasses Containing Morphine. J. Forensic Sci., 46: 12-14.

Introna, F.; Campobasso, C. P. and Goff, M.L. (2001): Entomotoxicology. J. Forensic. Sci. Int., 120:42 - 47.

Introna, F.; Lo Dico, C.; Caplan, Y.H. and Smialek, J.E. (1990): Opiate Analysis in Cadaveric Blowfly Larvae as an Indicator of Narcotic Intoxication. J. Forensci Sci., 35: 118122.

Ivey, P. (2011): Forensic Entomology: What can insects tell us post-mortem? Journal of Arts Science and Technology, 5 (1): 28.

Kharbouche, H.; Augsburger, M.; Cherix, D.; Sporkert F.; Giroud C.; Wyss C. et al. (2008): Codeine Accumulation and Elimination in Larvae, Pupae, and Imago of the Blowfly Lucilia Sericata and Effects on Its Development. Int J Legal Med., 122(3):205-211.

Kintz, P.; Tracqui, A. and Mangin, P. (1990): Toxicology and Fly Larvae on a Putrefied Cadaver. J Forensic Sci. Soc., 30: 243-246.

Kökdener, M. (2016): Application of Entomology in Forensic sciences. Türk. entomol. bült., 6(3):269-275. 
Mergaoui, L.; Belliman, M. Y. A.; Bouayoun, T.; El-Bouri, A. and Stambouli, A. (2007): "Chemical detection of cannabis resin traces and metabolites in corpse urine, excrement and entomological fauna, and its effect on decomposition". 5th Meeting of the European Association for Forensic Entomology (EAFE), P.68.

Moore, K.A.; Cina, S.J.; Jones, R.; Selby, D.M.; Levine, B. and Smith, M.L. (1999): Tissue distribution of tramadol and metabolites in an overdose fatality. Am J Forensic Med Pathol., 20(1): 98-100.

Nolte, K.B.; Finder, R.D. and Lord, W.D. (1992): Insect Larvae Used to Detect Cocaine Poisoning in a Decomposed Body. J. Forensci Sci., 37: 1179-1185.

Padonou, G.; Gnanguenon, V.; Osse, R.; Oussou, O.; Odjo, E.; Akinro, B. et al. (2017): First evidence of forensic entomology revealed the presence of arthropods on rabbit carrion in Cotonou, Benin (West Africa). Int J Entomol Res., 2(6): 94-98.

Paget, G.E. and Barnes, J.M. (1964): Evaluation of Drug Activities. In: Lawrence D.R. and Bacharach AL., eds. Pharmacometrics. New York, Academic press. p.p 161.

Pélissier-Alicot, A.L.; Gaulier J.M.; Champsaur, $P$. and Marquet, $P$. (2003): Mechanisms underlying postmortem redistribution of drugs: a review. J Anal Toxicol. 27(8):533-44.

Pothiawala, S. and Ponampalam, R. (2011): Tramadol Overdose: A Case Report. Proceedings of Singapore Healthcare, 20(3): 219-223.

Pujol-Luz, J.R.; Francez, P.A.C.; Ururahy-Rodrigues, A.; Constantino, R. (2008): The Black Soldier-fly, Hermetia illucens (Diptera, Stratiomyidae), Used to Estimate the Postmortem Interval in a Case in Amapá State, Brazil. J. Forensic Sci., 53: 476-478
Rahimi, HR.; Soltaninejad, K. and Shadnia, S. (2014): Acute Tramadol Poisoning and Its Clinical and Laboratory Findings. J Res Med Sci., 19(9):855-859.

Salimi, M.; Rassi, Y.; Ahmadi, B.; Chatrabgoun, O.; Jamshidi, R. and Rafizadeh, S. (2018): Effects of Morphine on the Biomass and Development Rate of Chrysomya Albiceps (Diptera: Calliphoridae), A Forensically Important Species. Trop. Biomed., 35. 560-570.

Skopp, G.; Lutz, R.; Gangmann, B.; Mattern, R. and Aderjan, R. (1996): Postmortem distribution pattern of morphine and morphine glucuronides in heroin overdose. Int. J. Legal Med. 109:118-124.

Spiller, D. (1996): Insect Colonization and Mass Production. In: Smith CN, editor. Houseflies. New York, Academic Press; 203-205.

Sukontason, K.; Bunchoo, M.; Khantawa, B.; Piangjai, S.; Sukontason, K.; Methanitikorn, R. et al. (2000): Mechanical Carrier of Bacterial Enteric Pathogens by Chrysomya Megacephala (Diptera: Calliphoridae) in Chiang Mai, Thailand. Southeast Asian J Trop Med Public Health, 31(1):157-161.

Sukontason, K.L.; Narongchai, P.; Sukontason, K.; Methanitikorn, R. and Piangjai, S. (2005): Forensically Important Fly Maggots in A floating Corpse: the First Case Report in Thailand. J Med Assoc Thai., 88:1458-1461.

Tabor, K.L.; Brewester, C.C. and Fell, R.D. (2004): Analysis of the Successional Patterns of Insects on Carrion in Southwest Virginia. J. Med. Entomol., 41: 785-795.

Vásquez, M. and Liria, J., (2012): Morfometría Geométrica alar Para La Identificación De Chrysomya Albiceps y $\quad C$. Megacephala (Diptera: Calliphoridae) de Venezuela. Revista de Bióloga Tropical, 60: 1249-1258. 
Verma, K. and Paul, R. (2013): Assessment of Post Mortem Interval, (PMI) from Forensic Entomotoxicological Studies of Larvae and Flies. Entomology, Ornithology \& Herpetology: Current Research, 2(1):1-4.
Whitworth, T. (2006): Keys to the Genera and Species of Blowflies (Diptera: Calliphoridae) of America North of Mexico. P Entomol. Soc. Wash., 108: 689-725. 


\section{الملخص العربي}

\section{تأثير الترامادول على يرقات كريزوميا البايسيبس التيس

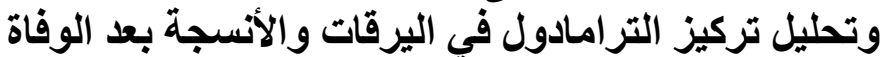
محمد ابر اهيم مخيمر الثهابي1،مهران فتحي مهران تونى1 ، عبد الباسط محمد أحمد عبد الرحيم'،نورة زيدان عبد اللاه²

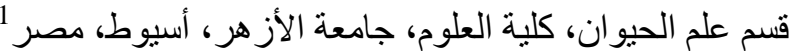

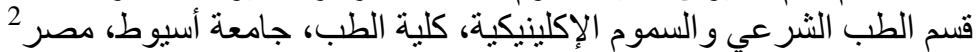

تعتبر ذبابة كريزوميا البايسيبس ذات أهمية طبية شرعية لأنها من أكثر الحشر ات التي تتو اجد بالجثث.

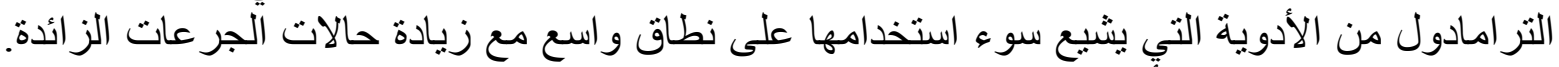

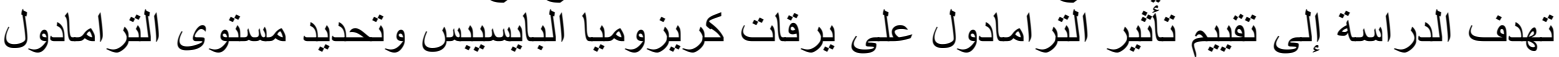

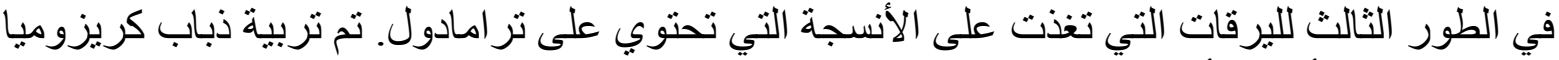

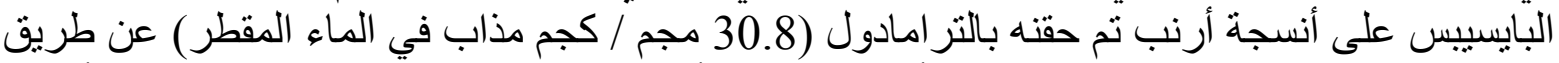

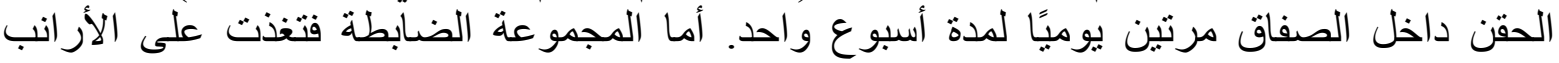

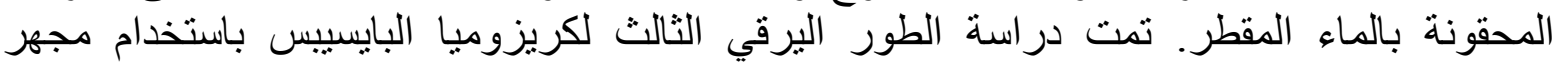

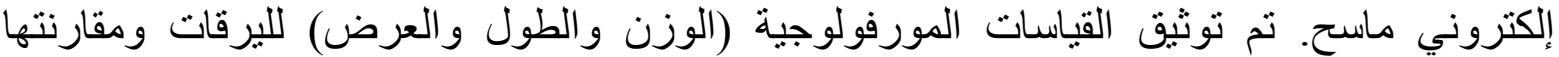

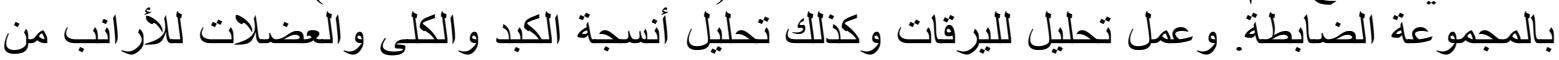

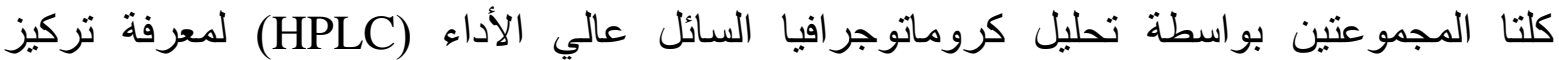

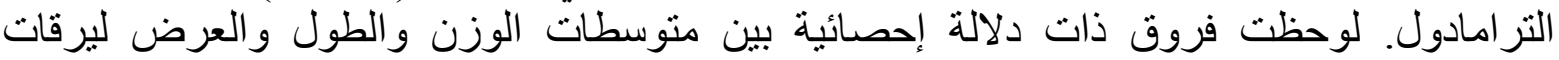

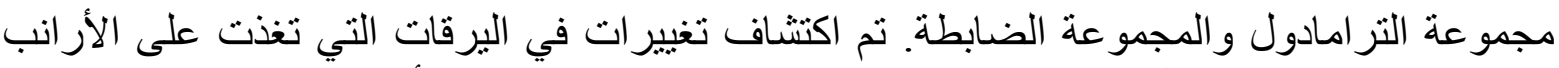

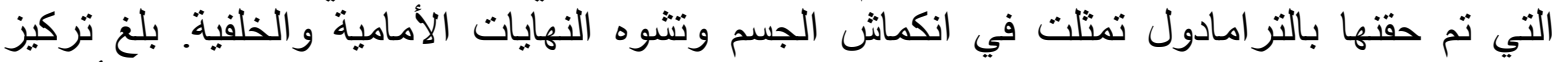

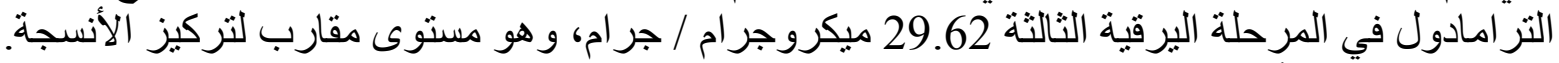

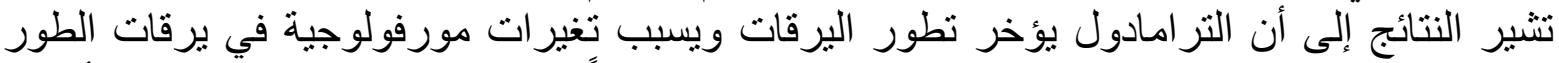

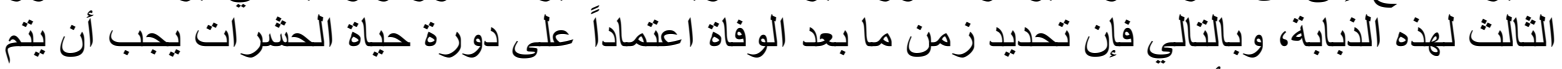

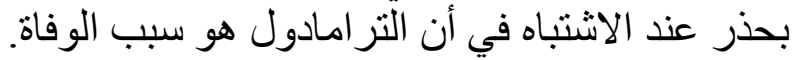

